\title{
Economic landslide susceptibility under a socio-economic perspective: an application to Umbria Region (Central Italy)
}

\author{
Marco Donnini' ${ }^{1}$ (D) ${\text { Marco } \text { Modica }^{2} \cdot \text { Paola Salvati }^{1} \text { Ivan Marchesini }}^{1}$ • \\ Mauro Rossi ${ }^{1}$ - Fausto Guzzetti ${ }^{1}$ - Roberto Zoboli ${ }^{3,4}$
}

Accepted: 25 July 2020 / Published online: 17 August 2020

(C) The Author(s) 2020

\begin{abstract}
An accurate understanding of physical and socio-economic effects of landslides is fundamental to develop more refined risk management, mitigation strategies and land use policies. In this paper we develop a measure to consider the interconnection between physical and economic exposure, i.e. what we call the economic landslide susceptibility, namely the probability of landslide occurrence in an area weighted for its socio-economic exposure considering the real-estate market values. The economic landslide susceptibility is estimated through a method designed for large areas that we applied to the Umbria Region (Central Italy). The method makes use of landslide susceptibility maps and a real estate market value map for any given area under analysis. The innovative concept of economic landslide susceptibility (that is de facto an ex ante landslide cost assessment) may be interpreted as the potential loss that an area might suffer in terms of its propensity for landslides. Useful applications of the proposed method lie in a better territorial management and in the land use planning.
\end{abstract}

Keywords Landslide susceptibility $\cdot$ Natural disaster $\cdot$ Land planning $\cdot$ Risk management

\section{Donnini}

marco.donnini@irpi.cnr.it

1 Istituto di Ricerca per la Protezione Idrogeologica (CNR-IRPI), Consiglio Nazionale delle Ricerche, Via Madonna Alta 126, 06128 Perugia, Italy

2 Social Sciences, Gran Sasso Science Institute, Via Iacobocci 2, 67100 L'Aquila, Italy

3 Università Cattolica del Sacro Cuore, Largo Gemelli 1, 20100 Milano, Italy

4 Istituto di Ricerca sulla Crescita Economica Sostenibile (CNR-IRCrES), Consiglio Nazionale delle Ricerche, Via Corti 12, 20133 Milano, Italy 


\section{Introduction}

Landslides are a widespread hazard, causing human fatalities in urban settlements, along transport corridors and at sites of rural industry (Froude and Petley 2018), representing the 7 th worldwide largest killer among natural disasters and producing heavy economic damages in many countries (Herath and Wang 2009). However, in the evaluation of landslide hazards the degree of tolerance of landslides risk by people, policy makers and stakeholders in general, turns out to be surprisingly high (Hungr et al. 2016). To develop more refined landslide risk management, mitigation strategies and land use policies, an accurate understanding of the triggering factors and of the physical and economic effects is fundamental (Field et al. 2012; Meyer et al. 2013; Paleari 2018). To produce effective results in reducing the risk of losses due to landslides and designing effective mitigation measures and land use planning it is necessary an interdisciplinary approach taking together physical and economic aspects (De Graff 2012; Prenger-Berninghoff and Greiving 2015).

Assessing landslide risk is a complex and uncertain operation, and it needs information regarding (i) the hazard $(\mathrm{H})$, expressed as the probability that a landslide of given magnitude (e.g. area or volume) will occur in a given area (susceptibility) in a given period, (ii) the vulnerability (V), the potential damage or losses that a landslide could cause (Guzzetti et al. 1999; Alexander 2005; Ardizzone et al. 2008; Merz et al. 2010), and (iii) the number and the type of the elements at risk (E) (Glade and Crozier 2005). Finally, the risk assessment can be used for the quantification of the potential economic losses due to landslide occurrence. Nevertheless, this goal might result hard to reach because the estimation of the possible losses due to landslides is a difficult task for the variety of potentially exposed elements (e.g. UNISDR et al. 2009), particularly important when looking at the urban context. The widespread presence of man and his activities has often led to an uncontrolled urban sprawl that exacerbates the effect of natural hazards (Geneletti et al. 2007).

For the complexity of this multi-level analysis, studies that include more than one type of exposed element are scarce (e.g. Michael-Leiba et al. 2003; Keiler 2004; Marin and Modica 2017; Promper and Glade 2016) and exhaustive landslide risk evaluations can be performed at local scale (site specific) (e.g. Cardinali et al. 2002). For wider areas, simplified approaches are preferred as a trade-off between the need to provide quantitative, reliable and reproducible estimations and the scarce and heterogeneous data available over wide areas.

In this paper, we defined an easy to understand and replicable measure for recognizing the propensity of a large area to suffer landslide damage and consequently for estimating the related potential economic losses. For this purpose, we proposed a simplified method that combines the landslide susceptibility (i.e. the probability of landslide occurrence in an area due to local conditions, see Brabb 1984; Guzzetti et al. 2005, 2006a, b) with the potential economic losses in terms of real-estate market values that turn to be a proxy for the overall economic exposure. We therefore are able to define a measure of the economic landslide susceptibility capable of capturing the probability of landslide occurrence in an area weighted for its socioeconomic exposure. This measure is able to provide a proxy of the relative potential socio-economic costs due to landslides of the area under analysis. Therefore, 
the economic landslide susceptibility might be thought as a synthetic indicator that captures the combined effects of the physical and the socio-economic aspects of an anthropized territory subject to landslide. The method is tested in a risky landslide prone region, Umbria (Central Italy), for the abundance of landslides both in rural and urban areas (Guzzetti et al. 2003) and for the availability of reliable landslide susceptibility models (Mateos et al. 2014).

Overall, our approach provides the economic values of areas that are susceptible to landslides. Therefore, we get closer to the potential losses (in relative terms) of an area considering the potential occurrence of landslides, at regional scale that is not common in this kind of literature. Aim of this study is to provide the propensity of an area in suffering a damage as input for land planning, providing the ground for enhanced decisions both in risk management and in land use planning, by means of an interdisciplinary approach. Defining the potential losses in relative terms (and not in absolute ones), two main issues might arise. Firstly, the replicability of the work is not guaranteed per se because it depends on the availability of homogeneous and standardized data. Secondly, defining the potential economic losses in terms of real-estate market values as a proxy for the overall economic exposure might lead to underestimated results in countries where informal or illicit settlements have relevantly high numbers. This might be particularly true in some cities around the world where informal settlements are located in places that are prone to disasters (see e.g. Berdegué et al. 2015; Iovino et al. 2020; Marx et al. 2013; and Pelling 2003). Thus, the evidence provided in this work does not allow a blind replication of the method without a preliminary adaptation that takes into consideration all these relevant issues, even though the relative interpretation of the results of our research might allow, in principle, an overall generalized application of the method presented in this paper.

Other important points to take into consideration are that: (i) the scarcity of economic performance data at urban or even sub-urban scale - that might be common in many countries - is in contrast with the detailed resolution of susceptibility maps; (ii) the direct estimate of potential economic costs caused by landslides should be done in an ex ante perspective as to better provide planning solutions for the policy makers; (iii) results should be replicable to other regions, and the choice of economic variables must be therefore beyond the local specialties. For all these reasons, we used the market value of buildings (price of property per $\mathrm{m}^{2}$ ), grouped by the typologies provided by the 'Osservatorio del Mercato Immobiliare' (OMI) of the Italian Revenue Agency in order to approach the socio-economic values of the area under analysis and to provide, in relative terms, a good proxy for potential losses caused by landslides in an ex ante perspective.

The reasons for this choice are several and in line with the concept of spatial equilibrium (see Takayama and Judge 1970; and Wieand 1987): (i) houses and lands are much more expensive in more amenable areas and cheaper in less favourable sites. This is true both considering the so-called natural amenities (e.g. pleasant climatic conditions), and the socio-economic benefit (e.g. proximity to the workplace, Di Pasquale and Wheaton 1996); (ii) population growth, income, wages, services, construction costs and taxes influence the market value of housing (Ozanne and Thibodeau 1983); (iii) empirical studies have shown a positive relationship between 
housing values and consumption (Haurin and Rosenthal 2006); (iv) changes in the economic value of houses have effects on income (Engelhardt 1994; Sheiner 1995); (v) the permanent income hypothesis of Friedman (Friedman 1957) seems to provide the first theoretical understanding regarding the wealth effect of housing prices. The intuition is simple: since housing is an important component of wealth of people, a (unexpected) higher or lower housing value affects the "expected lifetime wealth" of households (Miller et al. 2009); (vi) localization factors related to climate and socio-economic aspects are much more influential than the damage risk caused by natural disasters (Benson and Clay 2004). Therefore, the link between property value and economic performance, though not quite explicit, is in any case very robust. For this reason, the analysis of economic landslide susceptibility is based on the mapping of the market value of real estate weighted for the 'physical' susceptibility of an area subject to landslides.

One might observe that the economic susceptibility of different types of housing might change according to the type of buildings under consideration (e.g. residential buildings are different from productive buildings both in terms of exposure and vulnerability). However, we would like to stress that our value of exposure is a weighted value that takes into account the different types of buildings and it has to be read in relative terms according to the area under analysis. In fact, this is a synthetic relative value of an exposed area aggregated for all the types of housing values. However, this proxy can be disaggregated in the different components of property price buildings as to take into account the peculiarities of the area (e.g. we could define economic landslide susceptibility maps that show only the productive buildings). Overall, this work defines a methodology that can be adapted and modelled considering the socio-economic peculiarities of the different areas.

We organized the paper pointing out to the difficulties to combine the risk analysis and the economic evaluation in the land planning contest (Sect. 2), then we introduced the study area, i.e. Umbria Region (Central Italy) (Sect. 3). The input data and the method used are illustrated in Sect. 4 and in Sect. 5 respectively. In Sect. 6 our results are presented and finally, in Sect. 7 we discussed the method and in Sect. 8 we gave the main conclusions.

\section{Embedding the economic evaluation of landslide risk in land planning}

Notwithstanding the great landslide impact knowledge in Italy — that should be considered an underestimation of the real impact — land planning does not fully consider the potential landslide disaster risk of the country. Even if many efforts have been spent at European level for the flood risk management since the EU Flood Directive (2007/60/EC), less attention has been paid to landslide risk. Mysiak et al. (2013) reported that for a subset of the geo-hydrological risk-prone Italian municipalities $(\sim 30 \%)$, dwellings or whole residential quarters were located in areas exposed to landslides or in floodplains.

However, introducing risk analysis in land planning might be difficult for a series of issues. First, the stakeholders with different views and interests could lead to disagreements on the interpretation of analyses of earth science experts (Linne- 
rooth-Bayer and Patt 2016). This might turn out for instance in the debate on the actions that need to be implemented among stakeholders such as the possibility to implement structural measures to reduce the impact on the man-made environment. Secondly, embodying physical parameters to urban planning might result hard for the complexity of the matter that makes difficult the predictability of failure scenarios (Merz et al. 2010). Complexity that is also pushed by several factors as such the perceived reliability of specialists by citizenship, the risk perception or the immediate readability of the information and the relatedness of the results (Klimeš and Blahůt 2012). Lastly, in many countries it is possible to recognize a lack of legally binding regulations. Overall, even though there are regulations imposing the preliminary assessment of flood and landslide risk worldwide, these laws do not properly define the type of information required (i.e., susceptibility, risk analysis) and how this evaluation should be incorporated during the land planning process (Geneletti et al. 2007; Klimeš and Blahůt 2012; and Linnerooth-Bayer and Patt 2016). Therefore, risk knowledge and the measures to increase territorial risk reduction are not homogenous, even in a single country. They depend on several aspects that increase the uncertainty to define and to assess the risk of the areas and therefore the capacity to properly manage the territories as to appropriately face natural risks.

All these issues claim the needs for "decision makers, engineers, planners, and managers to take into account the physical parameters of the urban area, as well as the susceptibility to the natural hazards. The geology and the geomorphology of an area are important in the assurance of sustainable land management and in the protection of human life in urban areas" (Bathrellos et al. 2012). For all these reasons, a quick measure able to capture the propensity of an area in suffering a damage and the evaluation of potential socio-economic losses is now fundamental. This study, therefore aims at providing a quick methodological framework for land planning that is able to keep into consideration how an area is potentially susceptible to suffer a damage-intended as the monetary quantification of the degree of harm which structures, or other physical assets, have suffered because of an extreme event (Modica and Zoboli 2016) — that turns into a change in the wealth of people caused by the disruption of the socio-economic system. This will allow better planning prevention and mitigation strategies to reduce landslide costs and change in people's wealth.

\section{Study area}

Umbria is a Central Italy Region that lies along the Apennines mountains covering an area of $8456 \mathrm{~km}^{2}$ (Fig. 1). Its territory is predominantly hilly $(70.7 \%)$ with large open valleys that embrace the main rivers of the region. In the Region, Lake Trasimeno, the fourth lake for size in Italy, covers a large depression in the North-Western part of the region. The rest of the territory is mountainous (29.3\%) ranging from 700 to $2448 \mathrm{~m}$ at Cima del Redentore, in the Monti Sibillini range. The climate is Mediterranean, rainfall occurs mainly from October to December and from March to May and the cumulative annual rainfall ranges from 700 to more than $1300 \mathrm{~mm}$ (Guzzetti 2006). The Region is seismically active with a long earthquake history (Boschi et al. 1997), 
Fig. 1 Umbria Region map

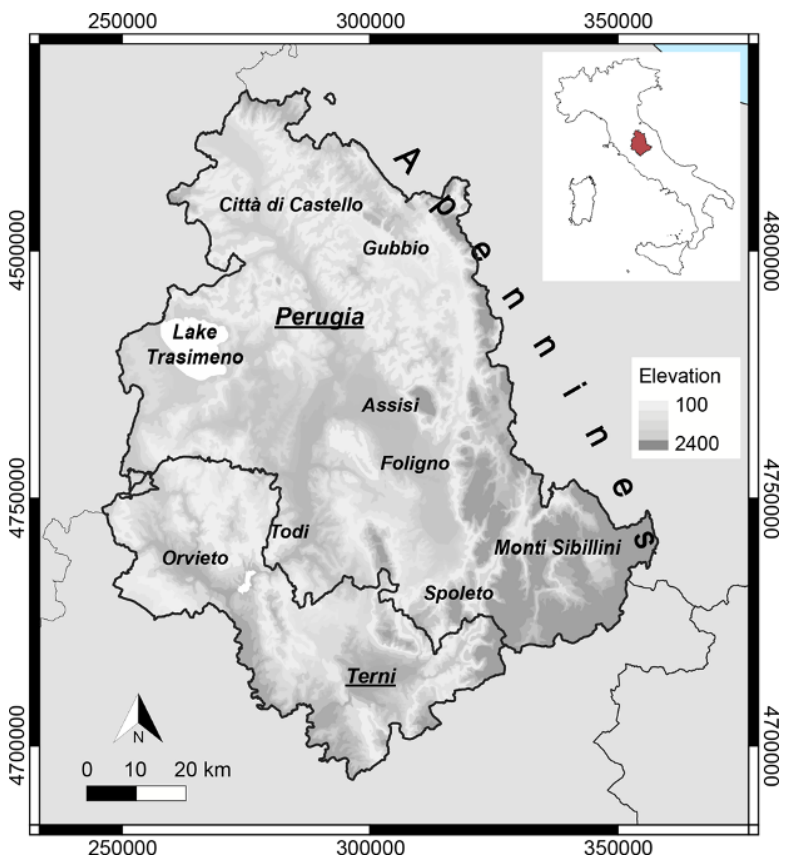

and destructive earthquakes are frequent (Bertolaso and Boschi 2007): between 1978 and 2017 Umbria has been affected by four large earthquake swarms that caused a large number of fatalities and buildings destruction especially in small villages. These earthquakes also triggered numerous landslides that produced multi-hazard effects on the man-made territories.

From a geological point of view, the Region is characterized by the presence of sedimentary rocks and subordinately volcanic rocks that show different geomorphological settings and typical geotechnical and hydrological properties (for details see Servizio Geologico Nazionale 1980; Guzzetti et al. 1996; Cardinali et al. 2002).

The Region is administratively subdivided in two provinces: Perugia and Terni. The main cities are Perugia, located in the Northern hilly sector of the Region, rich in historical sites and notable buildings, and Terni, located in a wide intra-mountain basin in the Southern part of the Region. Due to its geographical settings, the industrial sector is mainly developed in the surroundings of Terni, where important metallurgical and chemical plants are located, favoured by the abundance of water and hydroelectric power plants. The agricultural sector is highly developed in the Region, since most of the hilly areas are characterized by the presence of olive groves and vineyards.

Historical towns are abundant: pre-Roman and Roman sites are numerous along the flood plains while many ancient villages spread during the Middle Age at the top of hills mostly for defensive purposes. The landscape is the result of the interaction between natural processes and the continuous human activities. Due to its lithological, morphological, seismic and climatic setting, landslides are abundant (Felicioni et al. 1994; Guzzetti et al. 1996; Guzzetti 2006) and landslide inventories have been 
compiled in different times and for different purposes (Guzzetti and Cardinali 1989; Cardinali et al. 2001; Antonini et al. 2002) and therefore Umbria Region represents an interesting case study.

\section{Input data}

To model the economic landslide susceptibility, three different sources of data have been used: (i) the landslide susceptibility map in raster format available for Umbria Region by Mateos et al. (2014); (ii) the vector map of the real estate market values from the OMI (Osservatorio del Mercato Immobiliare) database of the Italian Revenue Agency (Osservatorio del Mercato Immobiliare 2018; www.agenziaentrate. gov.it); (iii) the vector map of the ISTAT census zones released by the Italian National Institute of Statistics-ISTAT (www.istat.it) containing the available data of the Italian national census population.

The method can be applied using different mapping units (e.g. administrative or morphological scales). For this work we used the ISTAT census zones that are the smallest territorial units for which ISTAT provides a large number of relevant data on population (e.g. age, sex etc. ...) and buildings (e.g. more frequent type and age of buildings) data. The data have been pre-processed to be uniform and aggregated in the same format (Sect. 5.1).

\subsection{Landslide susceptibility map}

Landslide susceptibility ( $S($ land $)$ ) is defined as the likelihood of a landslide occurring in an area based on local terrain conditions (Brabb 1984) expressing "where" landslides could occur (Guzzetti et al. 1999, 2005, 2006a, b). In other words, the probability of spatial (geographical) occurrence of slope failures (Chung and Fabbri 1999; Guzzetti et al. 2005, 2006a) fixed a set of geo-environmental conditions.

The landslide susceptibility map for Umbria Region has been developed by Mateos et al. (2014), and it was elaborated by applying a quantitative and statistical based approach model defined in Rossi et al. (2010) using the LAND-SE software version 1.0 (Rossi and Reichenbach 2016). The software implements a combination of multiple multivariate statistical probabilistic models, where a landslide inventory is used as dependent (or grouping) variable and a set of thematic information as independent (explanatory) variables. The model returns in output the posterior probability of a specific area (a pixel or a polygon) of being affected by landslides, which defines the landslide susceptibility. The main advantages of using LANDSE rely on: (i) the possibility to use different cartographic units (pixel-based or polygon-based); (ii) the capacity to perform different types of validation analyses; (iii) the ability to evaluate the model prediction skills and performances using contingency tables, ROC curves (Fawcett 2006) and success and prediction rate curves (Chung and Fabbri 1999, 2003); (iv) the possibility to provide results in standard geographical formats (shapefiles, geotiff); (v) the possibility to perform an optimization and stabilization of the modelling algorithms; and (vi) the possibility to estimate susceptibility model uncertainties. In this study, the landslide susceptibility model 
considers shallow and deep-seated slides, the most abundant landslide types in Umbria Region (Guzzetti et al. 2003). Other kinds of landslides, like debris/earth/mud flows and rock falls, are not considered in the map.

The map was realized by using the following environmental data:

- (i) the landslide inventory map of Umbria Region (Antonini et al. 2002);

- (ii) the Digital Elevation Model (DEM) Shuttle Radar Topography Mission (SRTM) version 2.1 (http://dds.cr.usgs.gov/srtm/);

- (iii) the Corine Land Cover 2006 obtained by the European Environment Agency (www.eea.europa.eu/data-and-maps);

- (iv) the Geological Map of Italy, at 1:500,000 scale, provided by the Institute for Environmental Protection and Research (ISPRA, Istituto Superiore per la Protezione e la Ricerca Ambientale); and

- (v) the Soil map of Italy, at 1:1,000,000 scale (Mancini 1966).

To elaborate the landslide susceptibility map of Mateos et al. (2014) the territory was subdivided in $90 \mathrm{~m} \times 90 \mathrm{~m}$ cells and the value of each input variable (the five environmental data) was calculated considering buffer squares (kernel) of different size $(5,7$, and 9 pixels). To perform the susceptibility zonation, the landslide inventory map was used as a grouping variable (i.e. presence or absence of landslide in each pixel), while the other environmental data were used as explanatory variables. Pixels were classified as unstable (value equal to 1) if the landslide area percentage within the surrounding kernel was above the $10 \%$, and as stable (value equal to 0 ) if lower. As discussed in the literature (Guzzetti et al. 2006a; Reichenbach et al. 2018; Bornaetxea et al. 2018; Schlögel et al. 2018), the choice of a landslide area threshold above/below which a mapping unit can be considered unstable/stable, can impact the susceptibility modeling outcomes. Such choice cannot be done a priori and it may depend on several factors, including landslide inventory type, landslide mapping uncertainties and susceptibility model configuration. For such reasons, according to the literature, different landslide area thresholds are selected, tested and used to derive different susceptibility zonations. The final landslide area threshold is the one that optimizes the susceptibility modeling performances. Similarly, to explore the effects of this choice, were considered two landslide area threshold values corresponding respectively to 10 and $55 \%$. The threshold value equal to $10 \%$ was selected because it gave the best model performances (Mateos et al. 2014).

The application in the Umbria Region (Fig. 2) allowed calibrating and identifying the threshold value $(\%)$ of landslide area to be considered unstable and the optimal dimension of the squared kernel to use in the calculation of the values of the input variables. The best results correspond to squared kernel of 5 pixels and to a threshold of landslide area equal to $10 \%$. A comparison among the results obtained considering three kernel sizes of 5, 7, and 9 pixels is described in Mateos et al. (2014) and a more accurate description of the results is illustrated in Appendix A.

In Fig. 2 the landslide susceptibility model results with a range between 0 (non-susceptible) and 1 (susceptible). Different colours indicate different landslide susceptibility $(S($ land $))$ levels: red, very high susceptibility $(0.80 \leq S$ (land $) \leq 1.00)$; orange, high susceptibility $(0.55 \leq S$ (land $) \leq 0.80)$; yellow, medium susceptibility $(0.45 \leq S($ land $) \leq 0.55)$; light green, low susceptibility $(0.20 \leq S($ land $) \leq 0.45)$; dark 
Fig. 2 Landslide susceptibility zonation. The bar plot shows the percentage distribution of the different susceptibility classes. ( $V L$ very low, $L$ low, $M$ medium, $H$ high, $V H$ very high. Modified after Mateos et al. 2014)

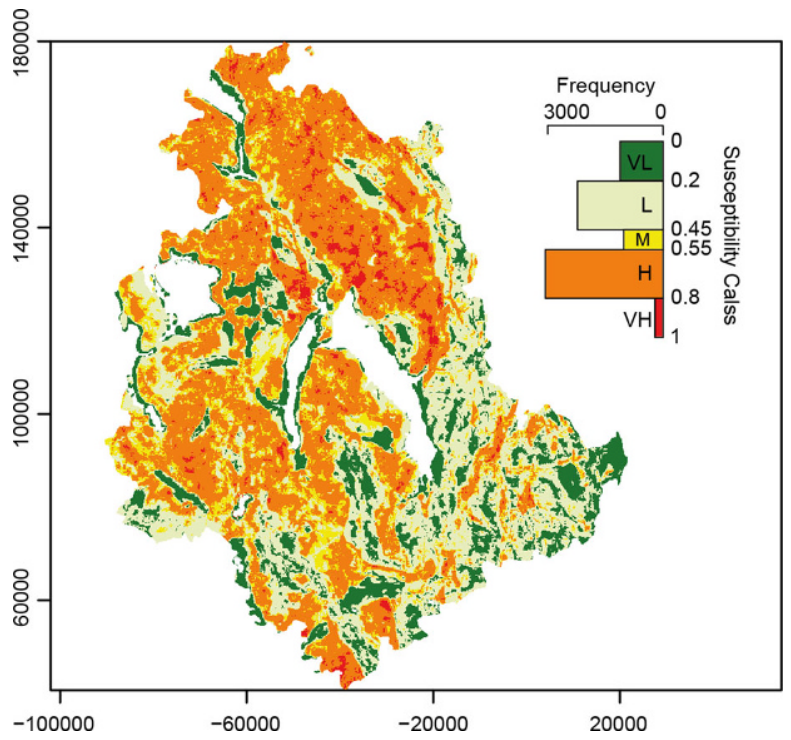

green, very low susceptibility $(0 \leq S($ land $) \leq 0.20)$. The bar plot shows the percentage distribution of the different susceptibility classes within the regional territory.

The optimal landslide susceptibility map reveals that the majority of the territory is widely susceptible to landslides including the urbanized areas of the capital city, Perugia, and of other minor cities as Todi, Orvieto, and Spoleto (for toponyms, refers to Fig. 1). Non-susceptible areas are restricted to the principal floodplains of the main rivers. Over $47 \%$ of the hilly and mountainous territory falls into high and very high susceptibility classes.

\subsection{Real estate market values polygons}

The real estate market values data of the OMI (Osservatorio del Mercato Immobiliare) database gives information on real estate prices for different types of buildings and it is available for the entire Italian territory (Osservatorio del Mercato Immobiliare 2017).

The OMI database provides: (i) differentiation of the municipalities into territorial areas as homogeneous as possible from the point of view of the prevalent category of real estate market (usually the residential); (ii) collection of economic data for individual real estate units; (iii) processing of acquired data; (iv) determination and updating of quotations for real estate units.

The OMI data is standardized and provides a synoptic view of the real estate prices. The database is updated every six months and contains information for the period 2002-2015. Table 1 shows 14 typologies of buildings (in Italian tipologia) grouped in four larger intended use building categories (in Italian destinazione): (i) residential (in Italian residenziale), (ii) commercial (in Italian commerciale), (iii) service sector (in Italian terziario), and (iv) productive (in Italian produttivo). Data are provided at a sub-municipal level since the municipality is divided in five 
Table 1 Description of the intended use categories of buildings as listed in the OMI database (AdTTecnoborsa 2008; Osservatorio del Mercato Immobiliare 2017). Definitions and descriptions are the English translation of the Italian terminologies. For completeness we reported the English/Italian version in the Appendix B

\begin{tabular}{|c|c|c|}
\hline $\begin{array}{l}\text { Intended use } \\
\text { category }\end{array}$ & Typology & Description \\
\hline \multirow[t]{6}{*}{$\overline{\text { Residential }}$} & Villa & Private house with garden \\
\hline & Refined house & Residential building with precious architectural features \\
\hline & Residential unit & Residential building with good general characteristics \\
\hline & $\begin{array}{l}\text { Economical } \\
\text { residential unit }\end{array}$ & Residential building with economical characteristics \\
\hline & Box and garage & Private isolated unit or part of a building dedicated to parking \\
\hline & $\begin{array}{l}\text { Covered/ } \\
\text { uncovered } \\
\text { parking }\end{array}$ & Private parking lot \\
\hline \multirow[t]{3}{*}{ Commercial } & Shop & Real estate unit intended for wholesale or retail commerce \\
\hline & $\begin{array}{l}\text { Shopping cen- } \\
\text { ter }\end{array}$ & Building or complex of buildings with shops \\
\hline & Warehouse & Real estate unit for commercial use \\
\hline \multirow{2}{*}{$\begin{array}{l}\text { Service } \\
\text { sector }\end{array}$} & Office & Real estate unit for office use \\
\hline & $\begin{array}{l}\text { Structured } \\
\text { office }\end{array}$ & Building for office use \\
\hline \multirow[t]{3}{*}{ Productive } & Shed & $\begin{array}{l}\text { Shed characterized by the homogeneity of the construction typol- } \\
\text { ogy and architectural features compared to the territorial area in } \\
\text { which it is located }\end{array}$ \\
\hline & Industrial shed & Shed used for industrial activity \\
\hline & Laboratories & $\begin{array}{l}\text { Real estate unit or building for tertiary destination, used for artisan } \\
\text { work of a non-business character, with possible retail sales }\end{array}$ \\
\hline
\end{tabular}

different types of territory named "OMI macro-area" (in Italian fascia): (i) B, central (in Italian centrale); (ii) $\mathrm{C}$, semi-central (in Italian semicentrale); (iii) D, peripheral (in Italian periferica); (iv) E, suburban (in Italian suburbana); and (v) R, rural (in Italian extraurbana).

The OMI macro-areas are then divided in OMI micro-areas (in Italian zona) with similar socio-economic and environmental conditions defined by an algorithm imposing the difference between maximum and minimum value of the real estate prices of the housing category lower than $50 \%$.

For each selected area, the OMI database contains information on: (i) the intended use category of the buildings, (ii) the more frequent type of building, (iii) the main status of conservation of the buildings (bad, normal, good), (iv) the minimum and the maximum estimated housing values $\left(€ / \mathrm{m}^{2}\right)$, and $(\mathrm{v})$ the rent values $\left(€ / \mathrm{m}^{2}\right)$.

In this work, we used values of the first semester of 2015. We considered all the four categories of real estate units shown in Table 1 (residential, commercial, service sector, productive) since these different values might proxy different economic exposure. Residential units are an important component of household wealth (Miller et al. 2009). Productive activities might proxy the potential direct and indirect damage derived by a landslide, or a more general natural disaster: direct in terms of loss of physical capital and stop of production activities, indirect in terms of inter- 
Table 2 Descriptive statistics of real estate market values $\left(€ / \mathrm{m}^{2}\right)$ for Umbria Region in the first semester of 2015. V(cat)min, V(cat)max, V(cat)mean, V(cat)median, and $V($ cat $)$ sd are, respectively the minimum, the maximum, the mean, the median and the standard deviation of the real estate market values observed for each intended use category (cat) of building

\begin{tabular}{llllll}
\hline $\begin{array}{l}\text { Intended use category } \\
(\text { cat })\end{array}$ & $V($ cat $)$ min & $V($ cat $)$ max & $V($ cat $)$ mean & V(cat)median & $V($ cat $)$ sd \\
\hline Residential & 562 & 2650 & 1061 & 1035 & 309 \\
Commercial & 386 & 2492 & 889 & 800 & 335 \\
Service sector & 710 & 2900 & 1406 & 1300 & 376 \\
Productive & 237 & 650 & 423 & 443 & 96 \\
\hline
\end{tabular}

ruption of the supply of intermediate goods (Marin and Modica 2017). Real estate market values vary in amount and in location. They are generally higher in urban areas, where residential buildings are more frequents, for the amenities. Production buildings are typically located in the surroundings of urban areas due to lower rent for land, environmental and landscape restrictions and proximity to the main road networks. Therefore, focusing on one aspect of the real estate market could lead to misleading land planning choices in relation to landslide risk assessment. Table 2 shows some descriptive statistics of real estate market values $\left(€ / \mathrm{m}^{2}\right)$ for the four intended use categories of units estimated for Umbria Region by using the OMI data of the first semester of 2015. In the table, V(cat)min, V(cat)max, V(cat)mean, $V($ cat $)$ median, and $V(c a t) s d$ represent, respectively the minimum, the maximum, the mean, the median and the standard deviation of the real estate market values observed for each intended use category (cat).

\subsection{ISTAT census zones polygons}

The vector map of census zones of Italy, released by the Italian National Institute of Statistics-ISTAT (www.istat.it), classifies, in the 2011 national census, the Italian territory in about 380,000 zones. The census zones are small or very small in urban areas, large in sub-urban areas, and large or very large in rural and mountain areas. In Umbria the size of the 7477 polygons ranges from $0.0002 \mathrm{~km}^{2}$ to $62.4 \mathrm{~km}^{2}$, with an average of $1.13 \mathrm{~km}^{2}$. To each census polygon, it is possible to associate information on number and intended use category of buildings. The method here proposed uses three of the numerous fields of the ISTAT census data. In detailed for each polygon we selected: (i) the number of residential buildings (classified by ISTAT as E3), (ii) the number of buildings for commercial, productive, service sector, offices, hotels and so on (classified by ISTAT as E4), in this paper defined as non-residential buildings, and (iii) the total number of inhabitants (classified by ISTAT as P1). Table 3 shows the correspondence of the ISTAT and OMI classification of buildings, Fig. 3a shows the density of residential buildings $(D($ res $))$ and Fig. $3 \mathrm{~b}$ the density of non-residential buildings ( $D$ (non res)). The densities are expressed as the number of buildings per square kilometer.

An observation of Fig. 3a points out that the highest values of residential buildings density ( $>100$ buildings $/ \mathrm{km}^{2}$ ) are observed in correspondence of the major urban areas of Perugia, Città di Castello, Gubbio, Assisi, Foligno, Terni, Spoleto and 
Table 3 Correspondence of OMI database and ISTAT classification of types and categories of buildings

\begin{tabular}{lll}
\hline $\begin{array}{l}\text { Intended use category } \\
(\mathrm{OMI})\end{array}$ & $\begin{array}{l}\text { Typology } \\
(\mathrm{OMI})\end{array}$ & $\begin{array}{l}\text { Category } \\
\text { (ISTAT) }\end{array}$ \\
\hline Residential & Villa & E3 \\
& Refined house & \\
& Residential unit & \\
& Economical residential unit & \\
& Boxe and garage & \\
Covered/uncovered parking & E4 \\
Commercial & Shop & \\
Service sector & Shopping centre & \\
Productive & Warehouse & \\
& Office & \\
& Structured office & \\
& Shed & \\
\hline
\end{tabular}

E3 residential buildings, E4 non-residential buildings

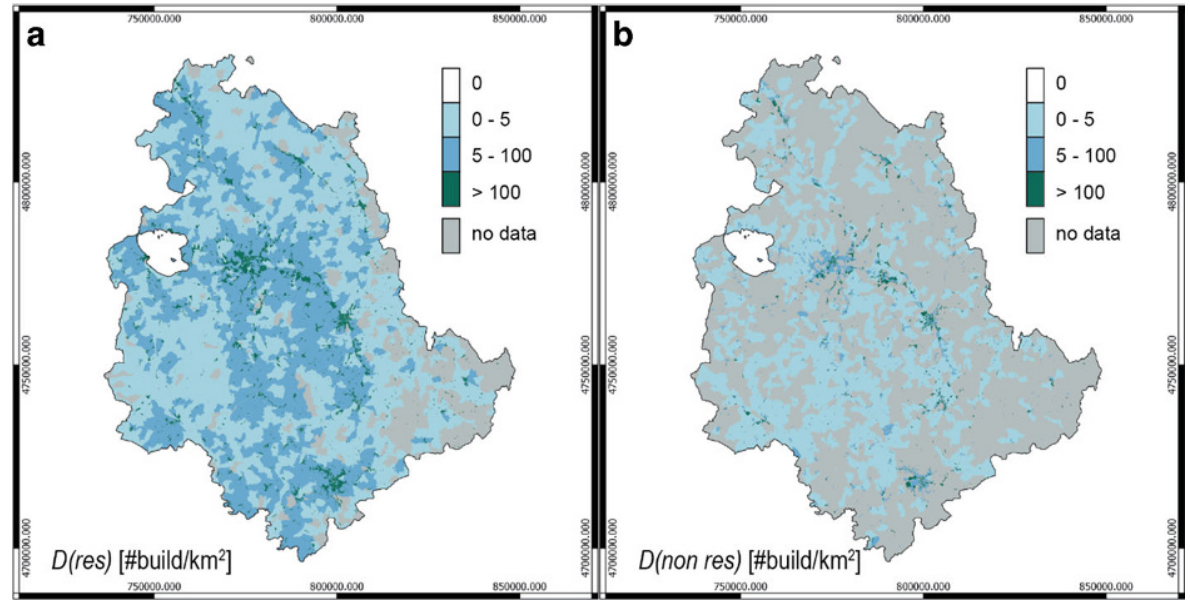

Fig. 3 a Density of residential buildings $(D($ res $))$ and $\mathbf{b}$ density of non-residential buildings ( $D($ non res $))$ expressed in number of buildings per square kilometre. The darker the colour the higher the density

Orvieto (for toponyms, refers to Fig. 1). Medium values of residential buildings density (between 5 and 100 buildings $/ \mathrm{km}^{2}$ ) are observed along the main valleys and in the surroundings of Terni. Low values of residential buildings density (between 0 and 5 buildings $/ \mathrm{km}^{2}$ ) are observed in the Eastern mountainous sector of the Region and in the surrounding area of Orvieto.

The map of non-residential building density (Fig. 3b) shows the highest values ( $>100$ buildings $/ \mathrm{km}^{2}$ ) in correspondence of the principal cities of the Region, medium values (between 5 and 100 buildings $/ \mathrm{km}^{2}$ ) in "spotty areas" of the Region, and low values in the Eastern mountainous sector of the Region. 
Fig. 4 Population density $(D(p o p))$ expressed in number of inhabitants per square kilometre. The darker colours are used for the highest values

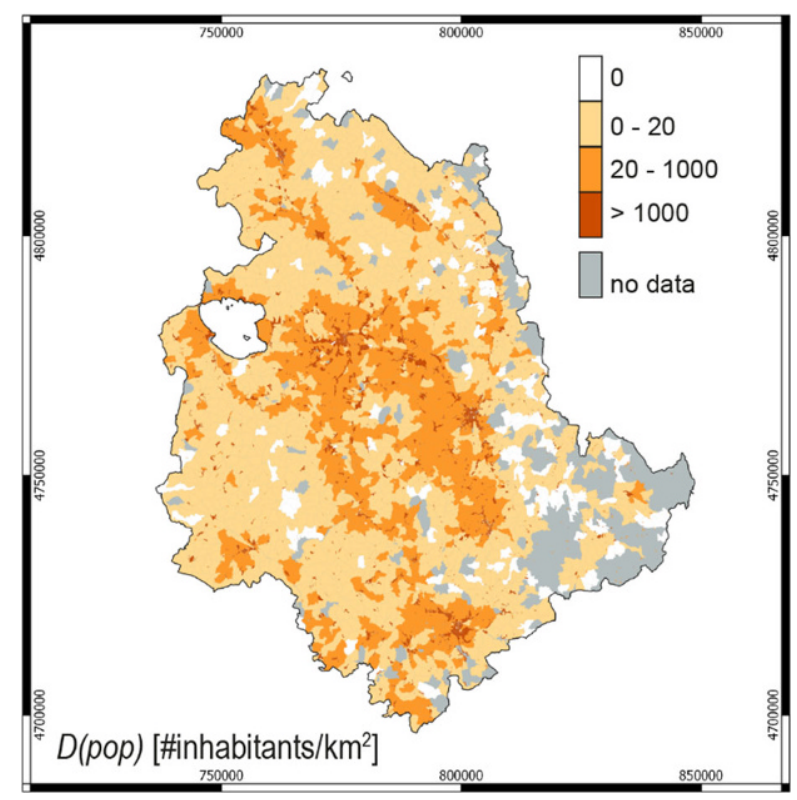

The population density $(D(p o p))$ expressed in the number of inhabitants per square kilometer released by the Italian National Institute of Statistics-ISTAT (www.istat. it) after the 2011 national census is shown in Fig. 4. ISTAT reports, for Umbria Region, a number of 884,257 inhabitants and the figure highlights that the highest values of population density ( $>1000$ inhabitants $/ \mathrm{km}^{2}$ ) are observed in correspondence of the major urban areas of Perugia, Città di Castello, Gubbio, Assisi, Foligno, Terni, Spoleto and Orvieto. Medium values of population density (between 20 and 1000 inhabitants $/ \mathrm{km}^{2}$ ) are observed along the main valleys and in the surroundings of Terni. Low values of population density (between 0 and 5 inhabitants $/ \mathrm{km}^{2}$ ) are observed in the Eastern mountainous sector of the Region, in particular in the Monti Sibillini range.

\section{Method}

The simplified method we present aims to assess for large regional areas the expected monetary degree of losses. The method consists of different steps, illustrated in Fig. 5, and takes different thematic data in input. We applied the method in the Umbria Region, but it is structured to be applied wherever data are available. Due to differences in the formats and resolution of the data sources, a pre-processing step is required in order to transform data in a workable format. 


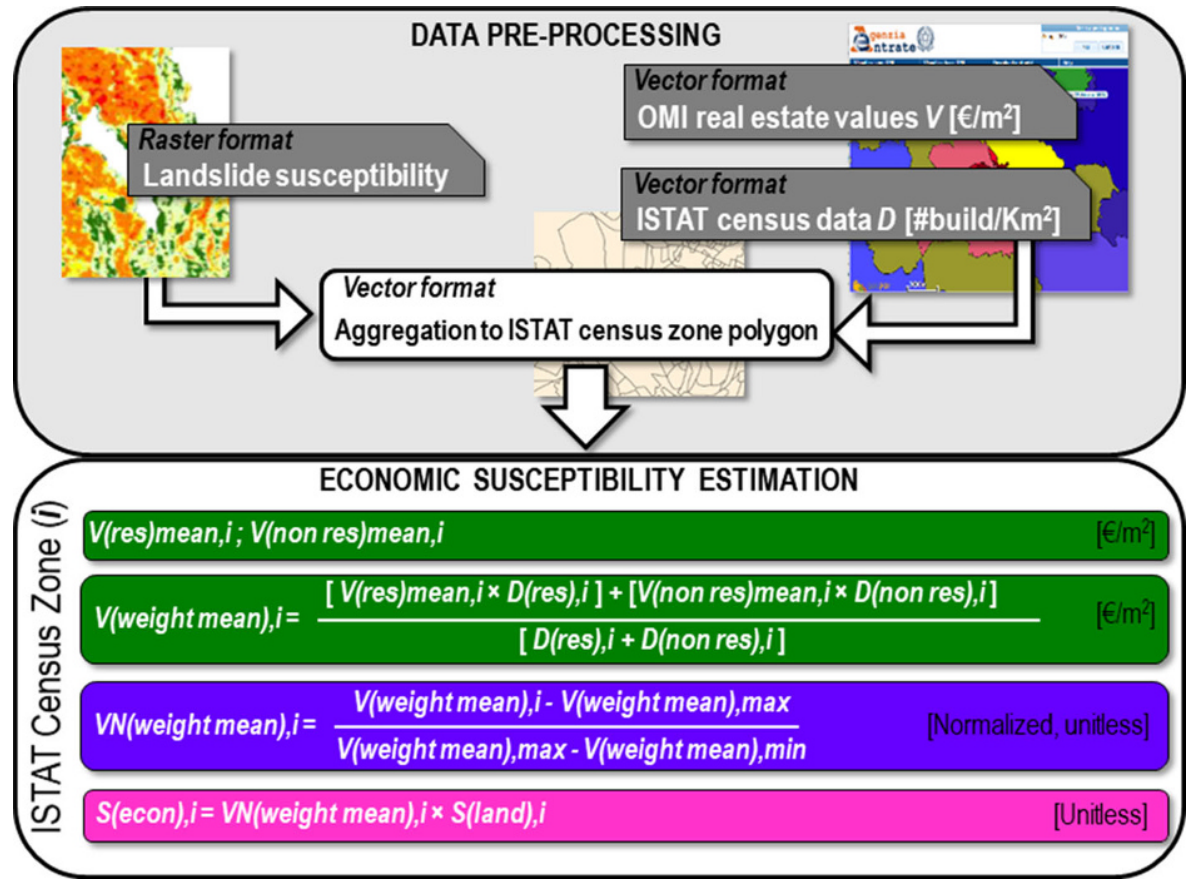

Fig. 5 Schematic workflow illustrating the different steps of the applied method. V(res)mean, $i$ and $V($ non res)mean, $i$ are, respectively, the mean estate market value for residential and non-residential buildings within a census zone $i$ and are expressed in $€ / \mathrm{m}^{2} . D($ res $), i$ and $D$ (non res), $i$ are, respectively, the density of residential and non-residential buildings within a census zone $i$ and are expressed in number of buildings for $\mathrm{km}^{2}$. VN(weight mean), $i$ is the normalized weighted mean real estate market value estimated within a census zone $i$ and it is unitless varying from 0 to 1 . V(weight mean),min and V(weight mean),max are, respectively, the minimum and the maximum weighted mean real estate market values observed in the study area and are expressed in $€ / \mathrm{m}^{2}$. S(econ), $i$ and $S$ (land), $i$ are, respectively, the economic landslide susceptibility and the landslide susceptibility, both unitless varying from 0 to 1

\subsection{Data pre-processing}

The data pre-processing is essential due to different topographic characteristics and spatial resolution of the two main database we used for defining the socio-economic values of the area under analysis (ISTAT and OMI).

More in details, the input data (in dark grey in Fig. 5) have different non-overlapping resolution: (i) the landslide susceptibility is a raster map with $90 \mathrm{~m} \times 90 \mathrm{~m}$ cells, (ii) the OMI real estate market values and (iii) the ISTAT census zones are represented by two vector maps with non-coincident polygons.

We adopted the resolution of ISTAT census zones as mapping unit, making homogenous all the other input data to this unit. The landslide susceptibility values $(S($ land $))$ were incorporated to each ISTAT census zones polygons by calculating the mean landslide susceptibility of each raster cell into the ISTAT polygons. In Fig. 6 the result of the aggregation of the landslide susceptibility within the ISTAT census zones polygons is shown. 
Fig. 6 Landslide susceptibility $(S($ land $)$ ) values (unitless and varying from 0 to 1 ) aggregated within the ISTAT census zones. ( $V L$ very low, $L$ low, $M$ medium, $H$ high, $V H$ very high)

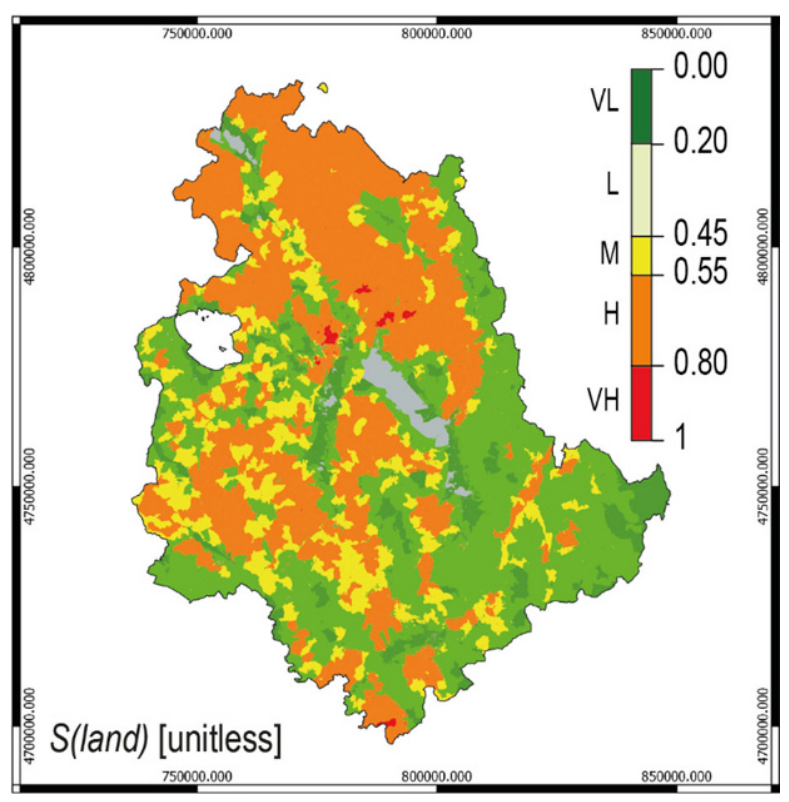

ISTAT Census Zone (i)

Intended use category (cat)

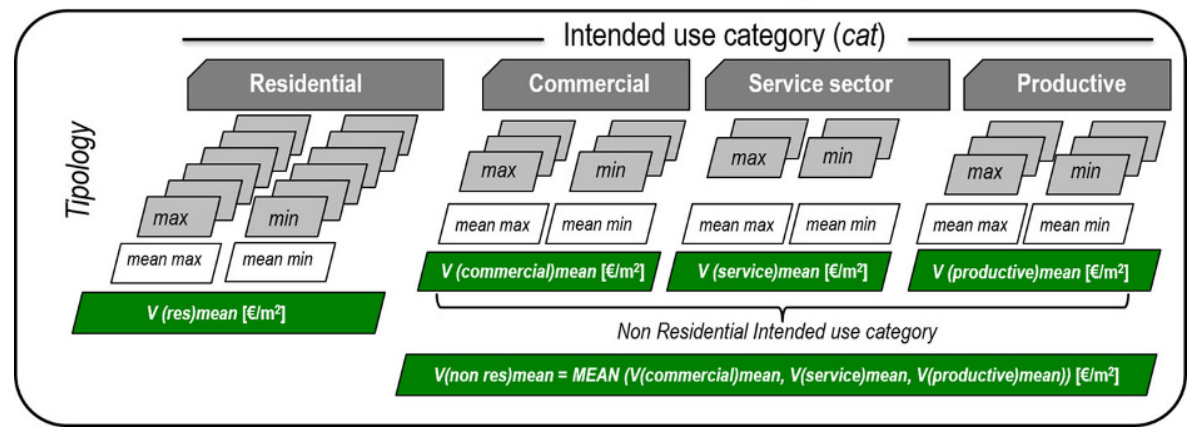

Fig. 7 Schematic sequence of the computational operation to assess the mean real estate market values for each census zone starting from the raw data available from the OMI database are: V(res)mean, $V($ commercial)mean, $V($ service $) m e a n, V($ productive)mean representing, respectively, the mean real estate market values for residential, commercial, service sector, productive buildings. V(non res)mean is obtained by the mean of the market values of the last three intended use categories (V(commercial)mean, V(service)mean, V(productive)mean)

The aggregation of the real estate market values to the ISTAT census zones polygons was more complex for the different classification of building included in the two databases and a normalization and aggregation of the different economic values was needed. The workflow in Fig. 7 shows graphically the sequence of the computational operation needed to assess the mean real estate market value for each census zone starting from the raw data available from the OMI database. In grey we portrayed, for each typology of buildings included in each of the four intended use 
category (cat), the two listed values: the minimum and the maximum. The simple means of the single minimum and the maximum values were used to calculate the mean real estate market values V(cat)mean (green in Fig. 7) for each intended use category within each ISTAT census zone $i$.

To be compliant with the ISTAT classification that lists two type of building categories (residential and non-residential that include buildings for commercial, productive, service sector, offices, hotels etc. ...) we calculated the average real estate market values for the residential and non-residential intended use category (commercial, service sector and productive) named respectively $V($ res $)$ mean and V(non res)mean ${ }^{1}$.

\subsection{Data normalization and economic landslide susceptibility estimation}

As shown in Fig. 5 where the method is schematically reported, to evaluate the economic landslide susceptibility values some steps were necessary. First we estimated for each census zone $i$, the weighted mean real estate market value ( $V$ (weight mean), $i$ ), expressed in $€ / \mathrm{m}^{2}$ according to the following equation:

$$
\begin{aligned}
& V(\text { weightmean }), i= \\
& \frac{[V(\text { res }) \text { mean }, i \times D(\text { res }), i]+[V(\text { non res }) \text { mean }, i \times D(\text { non res }), i]}{[D(\text { res }), i+D(\text { non res }), i]}
\end{aligned}
$$

where $V($ res $) m e a n, i$ and $V$ (non res)mean, $i$ are, respectively, the mean estate market value for residential and non-residential buildings within a census zone $i$ and are expressed in $€ / \mathrm{m}^{2}$, while $D($ res $), i$ and $D$ (non res), $i$ are, respectively, the density of residential and non-residential buildings within a census zone $i$ and are expressed in buildings for $\mathrm{km}^{2}$ (see Sect. 4.3).

We then normalized $V$ (weight mean), $i$ obtaining $V N($ weight mean), $i$, here named normalized weighted mean real estate market value, by applying the following equation:

$$
V N(\text { weightmean }), i=\frac{[V(\text { weighedmean }), i-V(\text { weighedmean }), \text { min }]}{[V(\text { weighedmean }), \text { max }-V(\text { weighedmean }), \min ]}
$$

where $V$ (weight mean), min and $V$ (weight mean), max are, respectively, the minimum and the maximum weighted mean real estate market values observed in the study area (Umbria Region) and are expressed in $€ / \mathrm{m}^{2}$, while $V N$ (weight mean), $i$ is unitless and varies from 0 to 1 .

It should be noted that a simple average of the observed values for each category, would lead to erroneous considerations relating to the true economic value of the area for two reasons: (a) the observed values for some intended use category are

\footnotetext{
1 We also faced two different categorical classifications: ISTAT defines residential vs non-residential buildings; OMI has residential, commercial, service and productive sectors. As a pre-processing strategy, we made the assumption that OMI commercial, service and productive buildings are all considered non-residential buildings in the ISTAT database.
} 
not available on the whole territory (i.e. it is unlikely that industrial buildings are localized in the downtown census zones); (b) the observed values for each category vary over a very different range of values. Therefore, a normalized value that incorporates all the aspects of real estate, is a better proxy for the assessment of the economic exposure.

Similarly to what was done for the buildings, the population was normalized. In this way, indexes are available for each census zone that represent the number of buildings and of the resident population. These indices are helpful to better understand the socio-economic condition of the Region and the potential landslide economic risk. The population density $(D(p o p))$ normalization taken into account the minimum and the maximum $D$ (pop) values observed in the study area by applying the following equation:

$$
D N(\text { pop }), i=\frac{[D(\text { pop }), i-D(\text { pop }), \min ]}{[D(\text { pop }), \max -D(\text { pop }), \min ]}
$$

where $D$ (pop), $\min$ and $D($ pop ), $\max$ are, respectively, the minimum and the maximum population density values observed in the study area (Umbria Region) and are expressed in inhabitants $/ \mathrm{km}^{2}$, while $D N($ pop $), i$ is the normalized population density (calculated within a census zone $i$ ) that is unitless and varies from 0 to 1 .

Finally, as shown in Fig. 5, the economic landslide susceptibility (S(econ),i) was estimated for each census zone $i$ as the product of the normalized weighted mean real estate market value $V N$ (weight mean), $i$ and the landslide susceptibility (S(land),i) following Eq. 4:

$$
S(\text { econ }), i=V N(\text { weightmean }), i \times S(\text { land }), i
$$

In this sense, $S$ (econ), $i$ is the product of two unitless variables ranging from 0 to 1 .

\section{Results}

In this section, we describe: (i) the results of the aggregation of the real estate market values to the ISTAT census zones polygons obtained in the pre-processing phase, (ii) the map of the normalized weighted mean real estate market values (VN(weighted mean )) by applying Eq. 2, and (iii) the combination of VN(weighted mean) with the landslide susceptibility (S(land)) in order to obtain the economic landslide susceptibility (S(econ)), an indicator of the possible degree of losses, using Eq. 4.

Fig. 8a-c show the estimated mean real estate market values for commercial (Fig. 8a), service sector (Fig. 8b) and productive (Fig. 8c) buildings (respectively $V($ commercial)mean, $V($ service $) m e a n$, and $V($ productive)mean $)$. The visual inspection of the figures highlights high differences among the economic values of the three non-residential intended use categories of buildings. This is particularly evident between the service and the productive sector that represent respectively the 


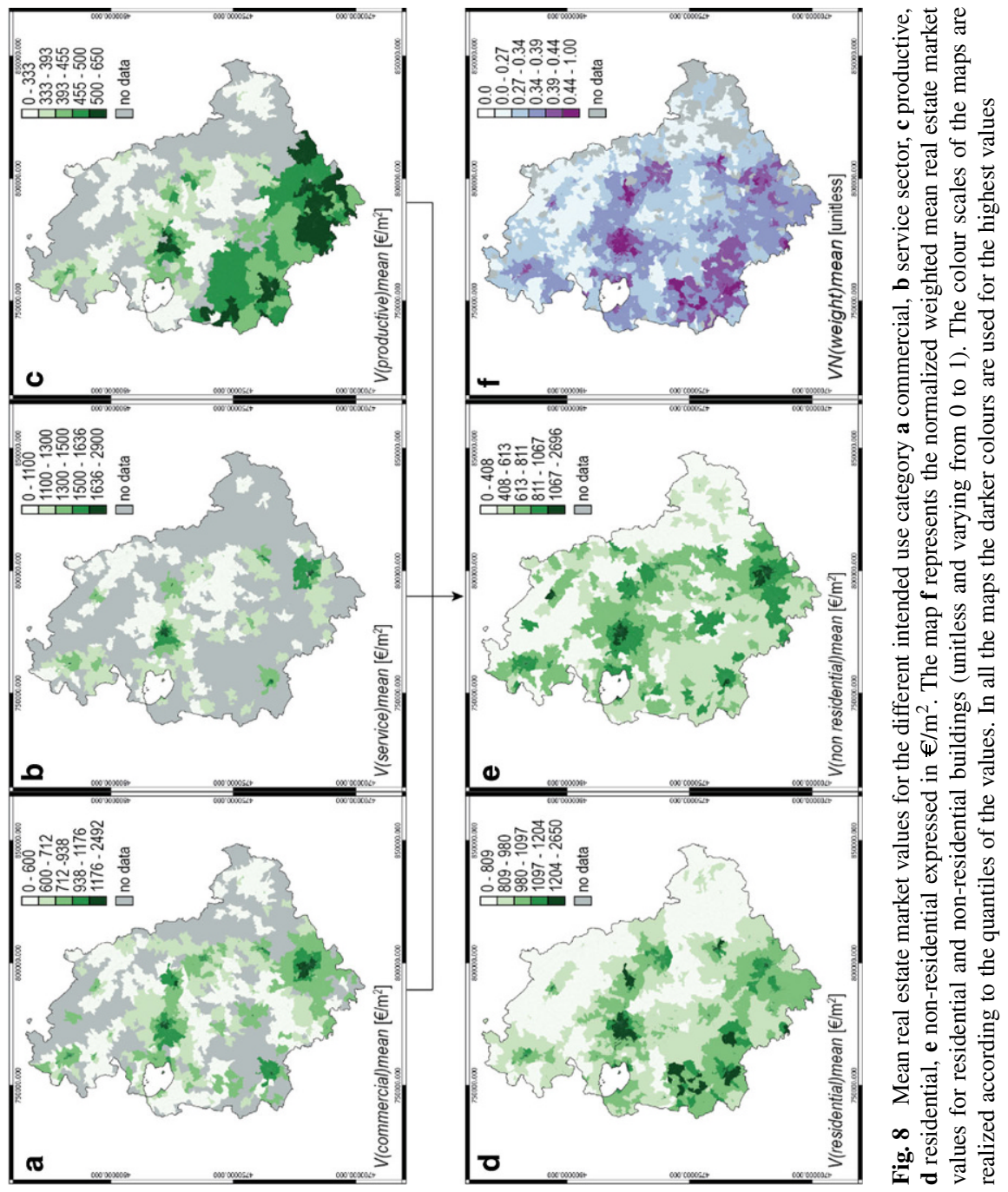

most expensive and the cheapest categories in Umbria. Regarding the residential sector, Fig. 8d, the map depicts how large the price differences of residential buildings throughout the Region are. The most expensive are concentrated in a limited number of census zones of the main regional city (Perugia) and in few areas of important historical centres (like Assisi and Orvieto). Fig. 8e shows the map of the mean real estate market value of non-residential buildings (V(non res)mean) obtained as the simple mean of the three maps of Fig. 8a-c. The figure shows that for the nonresidential sector, the highest values are distributed around the two major cities (Perugia and Terni) and their suburbs, while they are quite absent in the rest of the rural territory. Finally, Fig. 8f shows the normalized weighted mean real estate market 
Fig. 9 Economic landslide susceptibility (S(econ)), unitless varying from 0 to 1 . The colour scale of the map is realized according to the quantiles of the values. The darker the colours the highest the economic landslide susceptibility

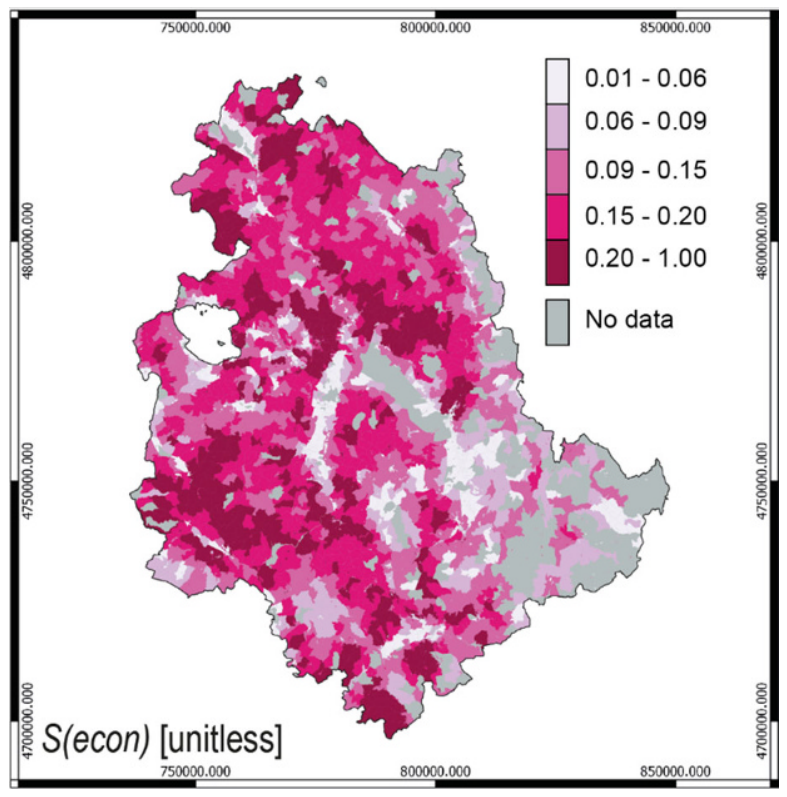

values for residential and non-residential buildings (VN(weight mean)) obtained as a result of application of Eq. 2.

The figures stress how the difference between urban and rural areas is a characteristic of the Umbrian territory still very strong. Fig. 8f highlights that the values of $V N$ (weight mean) are higher in the urban areas as it is expected for the high density of buildings in that areas. High values are observed also in the surrounding areas of Orvieto and in some census zones around the Trasimeno Lake for their high economic values. Low values are observed in the Eastern sectors of Umbria, corresponding to the scarcely populated mountainous areas of the Region as the results of the combination of low building density and economic values.

We used Fig. 9 and 10 to show the results of the economic landslide susceptibility (S(econ)) evaluation for Umbria Region obtained by applying Eq. 4. The map of Fig. 9 illustrates that highest $S($ econ) values are patchy distributed around the regional territory and the null values (grey in the map) are in the main river plains and in the mountainous uninhabited census zones in the Eastern part of the Region. The comparison with the landslide susceptibility map of Fig. 6 allows the comprehension of the distribution of the economic susceptibility to landslides reported in Fig. 9. The hilly and mountainous areas of the Region classified as susceptible or highly susceptible to landslides do not always demonstrate high economic susceptibility values because they correspond to the rural and uninhabited areas of the Region. On the contrary, high economic susceptibility values are numerous through the hilly surrounding of the major cities (e.g. Perugia, Todi, Orvieto, Terni) due to the high $V N$ (weight mean). Since the map of Fig. 9 is the combination of more than one variables, the simple observation of the map do not allow to discriminate if high $S$ (econ) values come from high $V N($ weight mean) or high $S$ (land) values (see equation Eq. 4). 
Fig. 10 Plots in $\mathbf{a}$ and $\mathbf{b}$ show the landslide susceptibility $(S($ land $))$ values vs the normalized weighted mean real estate market values (VN(weight mean)). The colour and the sizes of the circles in a represent the economic landslide susceptibility (S(econ)) values and the contour lines in $\mathbf{b}$ give a measure of the distribution of the $S$ (econ) values a$$
\text { a }
$$

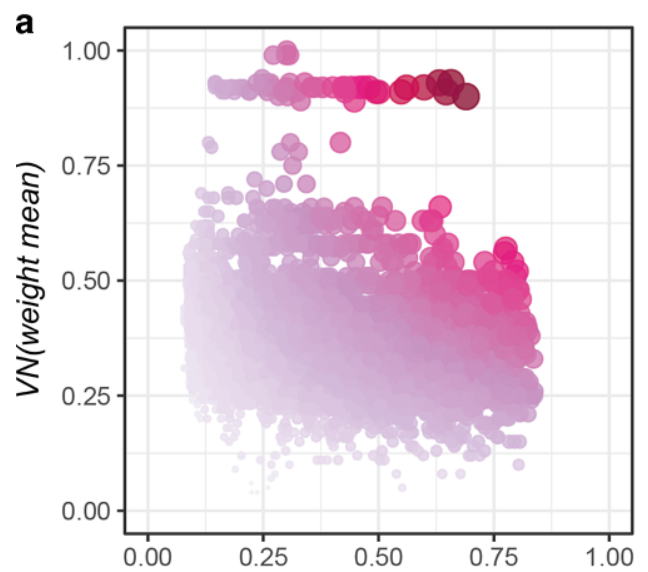

S(econ)

- 0.2

0.4

0.6

S(econ)

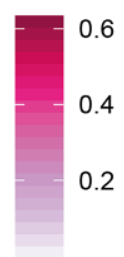

b

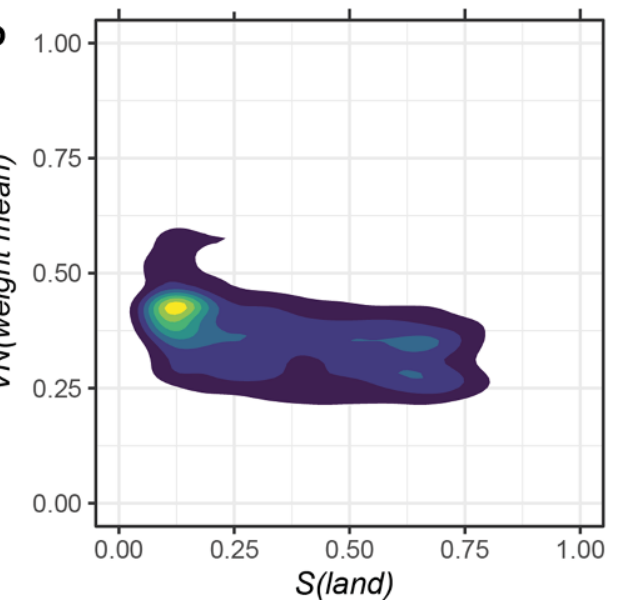

level

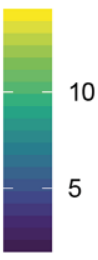

To overcome this problem, we introduced the two plots shown in Fig. 10a, b. In both figures in the X-axis we put $S$ (land) and in the y-axis we put VN(weight mean). In Fig. 10a, the colour intensity and the size of the circles increase with $S$ (econ). By the relative position of the circle it is possible to discriminate which term of equation Eq. 4 contributes to $S($ econ) evaluation.

\section{Discussions}

The scientific and technological advancements in the last ten years have brought the prediction of spatial probabilities of the occurrence of landslides (susceptibility) to high levels, even for large territories. As a consequence, susceptibility models are widely diffused and susceptibility maps are easily available. Conversely, the possibility to assess the landslide hazard is quite limited by the complexity and unavailability of data required to estimate the temporal and the magnitude probabilities, in particular for large areas, from regional to national level. The impossibility 
of defining the landslide hazard cannot become an "insurmountable barrier" that limits the prospect of further analysis and evaluations. For this purpose, we proposed a simplified method that assumes the landslide susceptibility to be an optimal base layer as a compromise between the opportunity to obtain a complete landslide risk scenario, possible at local scale (site specific), and a simplified but replicable one, applicable to large territory (national level). The success of the method here presented, strongly depends on the uncertainty of the estimated landslide susceptibility values and on the reliability of the assessed real estate market values. To minimize the effect of the landslide susceptibility uncertainty on the calculation of S(econ) (Eq. 4), we used an optimal landslide susceptibility model combination, which has a significant lower variability compared to single models, as suggested by Rossi et al. (2010). Despite this, we acknowledged that susceptibility uncertainty cannot be removed completely, and it is larger for intermediate values; in the Umbria case study, the maximum estimated uncertainty value was 0.003 for $S($ land $)=0.5$. We also acknowledge that real estate market values have a certain degree of uncertainty, which was taken into account when calculating VN(weight mean) (Sect. 5.2). Indeed, a proper interpretation of the economical susceptibility values $S$ (econ), should always consider the uncertainties associated with its estimation.

Despite the abundance of landslide susceptibility models and maps available worldwide at different scales (Reichenbach et al. 2018), we decided to apply our methodology to Umbria Region for different reasons. The first reason is for the reliability of the landslide susceptibility map elaborated "in house" for that region (Mateos et al. 2014) by applying a replicable method that follows the concept of "open science" (Nüst et al. 2018). The second reason is due by the fact that Umbria region is a hilly region where both landslides (Felicioni et al. 1994; Guzzetti et al. 1996; Guzzetti 2006) and landslide inventories (Guzzetti and Cardinali 1989; Cardinali et al. 2001; Antonini et al. 2002) are abundant. Moreover, Umbria Region is characterized by different land-use: (i) widespread rural areas, where small rural industries are very common, (ii) urban areas (mainly developed in correspondence of historical centres like Perugia, Assisi and Orvieto), and (iii) industrial areas, with important metallurgical and chemical industries (mainly in the province of Terni). These differences are well evident by the peculiar real estate market values for the different typologies of buildings (see Fig. 8 and Table 2) that range from a mean of $423 € / \mathrm{m}^{2}$ for productive (ranging from 237 to $650 € / \mathrm{m}^{2}$ ) to a mean of $1406 € / \mathrm{m}^{2}$ for service sector (ranging from 710 to $2900 € / \mathrm{m}^{2}$ ).

The economic landslide susceptibility model here presented could be applied by using any type of landslide susceptibility model.

Although the method was structured to be widely applicable, the main limits can consist in the combination of landslide susceptibility with socio-economic data that can be fragmented and not uniform. In the case study of Umbria Region, as well as for the Italian territory, a pre-processing of the data was necessary. In this way, the inhomogeneity of the data does not represent a limit and can be applicable even in other countries with different structure of the data.

About data availability, in Italy real estate market values and building density values are released by national organizations (the Italian Revenue Agency and the Italian National Institute of Statistics-ISTAT) and for this reason they are available 
in the same format for all the 20 Italian regions. The use of more detailed data, e.g. at building scale, could allow a better discrimination of the 6 typologies of residential and the 8 typologies of non-residential buildings shown in Tables 1 and 3. The main difficulty of applying our method worldwide is on the accessibility of real estate market values and building density values, since we are aware that not all the nations have the same data availability.

We express the potential losses (i) in absolute terms considering the different category of buildings reported by the OMI database (see Fig. 8), (ii) in relative terms as the normalized mean value weighed by the building density for different typologies of real estate units (VN(weight mean)). A synoptic view of $V N($ weight mean), $S$ (land) and S(econ) is shown in Fig. 10. In particular, Fig. 10a shows firstly a discontinued trend of $V N$ (weight mean) with the majority of the points under the 0.5 value, and secondly that the majority of census zones with high $S$ (land) values have relatively low $V N$ (weight mean) values. This distribution is more evident in Fig. 10b, where the contour lines give a measure of the distribution of the $S$ (econ) values highlighting that the most abundant values have low $S$ (econ) (>0.25) and medium-low $V N$ (weight mean) (between 0.25 and 0.5 ) values. Overall, the figure shows that areas with a high economic value but with low landslide susceptibility (and similar areas with low economic value and high landslide susceptibility) are characterized by low economic risk values. In contrast, areas with high economic value and high susceptibility to landslides are characterized by a high economic risk.

The results obtained for the Umbria Region give evidence of a low potential economic losses due to landslides since the census zones with $S$ (econ) values greater than 0.5 are 7 for a total value of $0.07 \mathrm{~km}^{2}$ corresponding to a small percentage of the entire region, with prevalence of residential buildings (120 residential buildings vs 7 non-residential buildings).

Fig. 11 Plot showing the economic landslide susceptibility (S(econ)) vs the normalized population density $(D N(p o p))$

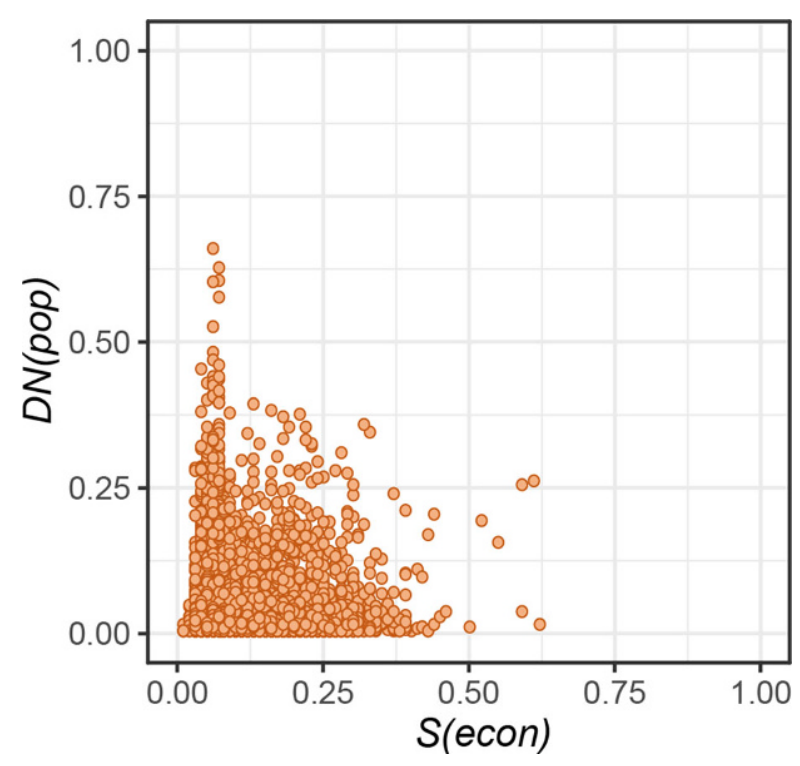


To better understand the socio-economic condition of the Region and the potential landslide economic risk, we decided to combine $S$ (econ) with a measure of the population density, i.e. $D N($ pop $)$ calculated by applying Eq. 3. The combination of $D N($ pop $)$ and $S$ (econ) is shown in Fig. 11, where in the x-axis of the figure we put $S$ (econ) and in the y-axis we put $D N($ pop $)$. The figure shows that the majority of census zones are characterized by medium-low $D N($ pop $)$ and $S$ (econ) values (both $<0.5)$ and that the most populated areas $(D N($ pop $)>0.5)$ are characterized by very low $\mathrm{S}(\mathrm{econ})$ values $(<0.1)$. In this sense the population exposed to economic landslide risk is quite low.

\section{Conclusions}

It is widely acknowledged that the assessment of the potential economic losses due to natural hazards is not an easy task (Donnini et al. 2017; Modica et al. 2019) especially when it has to be evaluated for large areas. It requires a huge amount of data and the combination of different expertise being at the boundary between science, technology, economy and politics, including planning and policy making (Guzzetti 2006). In this sense the possibility to apply a unique methodology allows land planner and civil protection deciders to classify the territory based on the economic loss identifying areas where concentrate mitigation efforts to preserve the building heritage. Therefore, we provided a general methodology that might be applied to different territories and even to different countries. However, even though the method is as general as possible, its application has to be calibrated according to the different types, characteristics and sources of data inputs, requiring pre-processing actions that might result in slight modification in terms of research approach.

The methodology here proposed has been shaped in relative terms for supporting policy makers to implement prevention and mitigation actions and to underline potential "hotspots" that need to be carefully monitored. This relative perspective is helpful to overrule the main issues underlined above indicating policy priorities in the land use management of specific regions, in relative terms. In a situation of scarce resources and budget constraints (more typical after the Great Recession and for country such as Italy), we provide a tool able to support territorial administrations to better allocate money to reduce as much as possible potential negative outcomes of landslides and to improve the efficiency of public expenditure.

Using the proposed method, it is possible to identify areas where the economic losses due to potential landslide events resulted high and this information can be easily applied for both insurance and land planning aims. The quantification of the potential losses can lead to the selection of where to mitigate and how many economic resources invest under a cost-benefit perspective.

Since the quantification of the real economic impact due to landslides is widely underestimated (Schuster and Highland 2001), if not ignored, in many hilly and mountainous areas the effective impacts on the economic system is very high and the evaluation of the landslide economic susceptibility could be of particular relevance at regional or national level. The innovative concept of the economic landslide 
susceptibility that we proposed, i.e. the probability of landslide occurrence in an area weighted for its economic exposure, can be considered as a good proxy for economic risk posed by landslide events.

The knowledge produced in this paper represents a first step in the integration process of the propensity of an area in suffering a damage within land planning, by means of an interdisciplinary approach which allows to collect available knowledge developed in different fields. In this way, the analysis provides the ground for enhanced decisions both in risk management and in land use planning.

Therefore, the aim of this work is to support policy makers and stakeholders in general, with a reproducible and easy-to-apply methodology aimed at mapping landslide susceptibility and economic risk assessment. In this way these easy-to-read maps can provide immediate understandable information over detailed areas, that can support policy makers in the implementation of adequate mitigation and prevention measures and in the choice of priority areas where to implement appropriate actions.

\section{Web sites}

- www.agenziaentrate.gov.it, accessed 29 October 2019

- www.istat.it, accessed 29 October 2019

- http://dds.cr.usgs.gov/srtm/, accessed 29 October 2019

- www.eea.europa.eu/data-and-maps, accessed 29 October 2019

Acknowledgements The work was conducted in the framework of the national project "Valutazione Economica dei Disastri Naturali" (Economic Evaluation of Natural Disasters) funded by Fondazione Assicurazioni Generali. We are grateful to the two anonymous reviewers that significantly contribute to the overall quality of the manuscript.

Open Access This article is licensed under a Creative Commons Attribution 4.0 International License, which permits use, sharing, adaptation, distribution and reproduction in any medium or format, as long as you give appropriate credit to the original author(s) and the source, provide a link to the Creative Commons licence, and indicate if changes were made. The images or other third party material in this article are included in the article's Creative Commons licence, unless indicated otherwise in a credit line to the material. If material is not included in the article's Creative Commons licence and your intended use is not permitted by statutory regulation or exceeds the permitted use, you will need to obtain permission directly from the copyright holder. To view a copy of this licence, visit http://creativecommons.org/licenses/by/4. $0 /$.

\section{Appendix A}

The methodology to elaborate the landslide susceptibility map of Umbria Region used in this work, and shown Fig. A.1, is described in Mateos et al. (2014). In this section we illustrated some of the results of the applied landslide susceptibility model.

The fourfold (or contingency) plot in Fig. A.1b represents graphically the contingency table obtained comparing observed (stable or unstable pixels) and predicted data. For the purpose, predicted landslide susceptibility values were classified by using a probability threshold equal to 0.5 (i.e. values ranging from 0 to 1 are clas- 
a

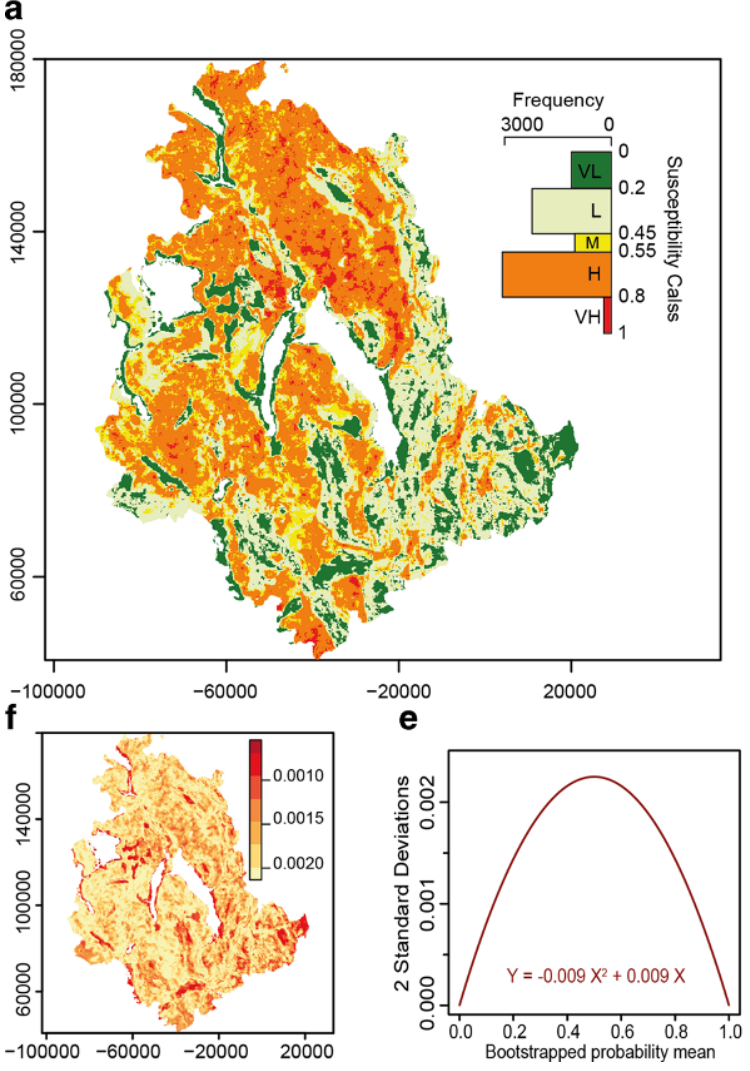

b

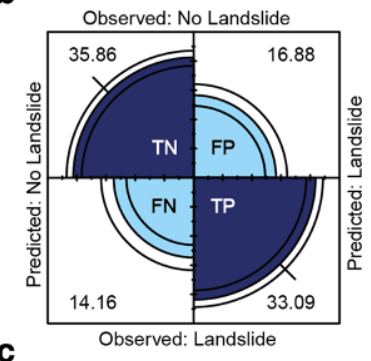

C

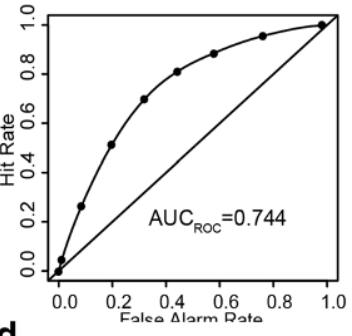

d

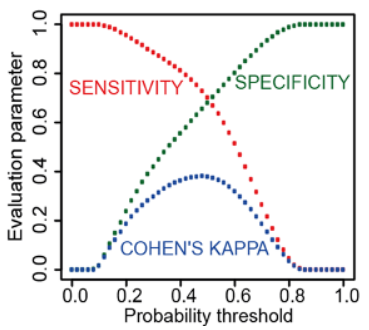

Fig. A.1 a Landslide susceptibility zonation with the relative distribution of the different susceptibility classes ( $V L$ very low, $L$ low, $M$ medium, $H$ high, $V H$ very high), b fourfold plot, $\mathbf{c}$ ROC curve (Receiver Operating Characteristic), $\mathbf{d}$ graph of sensitivity (hit rate), e uncertainty plot, and $\mathbf{f}$ uncertainty map. All the maps and the plots are derived from Mateos et al. (2014) considering the susceptibility model with a kernel size of 5 pixel and a landslide threshold of $10 \%$

Table A.1 Numerical parameters derived by the graphs shown in Fig. 2b-d

\begin{tabular}{ll}
\hline Contingency parameters & Value \\
\hline True negative, TN & 35.8 \\
False Positive, FP & 16.9 \\
True Positive, TP & 33.1 \\
False Negative, FN & 14.2 \\
Overall accuracy, (TN + TP) / (TN + FP + FN + TP) & 68.9 \\
Sensitivity (Hit Rate), TP / (TP + FN) & 0.70 \\
Specificity (True Negative Rate), TN / (FP + TN) & 0.68 \\
Optimal probability threshold & $\approx 0.5$ \\
Sensitivity and specificity curves intersection & $\approx 0.7$ \\
Maximum of kappa di Cohen coefficient & $\approx 0.4$ \\
Area under the ROC curve, AUCROC & 0.74 \\
\hline
\end{tabular}


sified as 0 or 1 ). In Table A.1 the corresponding values of the true positive (TP), true negative $(\mathrm{TN})$, false positive $(\mathrm{FP})$, and false negative $(\mathrm{FN})$ rates, the overall accuracy, the sensitivity rate, the specificity or true negative rate, and Kappa Cohen Coefficient are listed. Analysing the results obtained for the 5 pixels kernel, both sensitivity and specificity values are greater than 0.5 (accuracy 0.7 and specificity 0.68 ), showing that more than the $50 \%$ of the stable and unstable area is correctly classified. A measure of the model performance is given by the ROC curve (Fawcelt 2006) obtained for the kernel sizes of 5 pixels shown in Fig. A.1c. In the graph the area under the ROC curve (AUCROC) is an index of the performance of the model, an equal value of 1 indicates a perfect prediction of the observed data, a value of 0.5 indicates a bad performance of the model, a value less than 0.5 indicates an opposite prediction. The optimal probability to be used for the binary susceptibility classification is shown in Fig. A.1d. The specificity, the sensitivity and the Cohen's kappa values (along the y-axis) are obtained by comparing the grouping variable with the susceptibility values classified as 0 or 1 (stable and unstable) considering different probability thresholds (x-axis). In the graphs, the values obtained for a threshold of 0.5 are reported in Table A.1. The optimal probability to be used is the intersection between the sensitivity and specificity curves, and corresponding to the maximum value of the Cohen kappa curve. Fig. A.1e reports, for the 5 pixels model, the uncertainty plot which shows the variability of the susceptibility values obtained through a resampling bootstrap procedure (Rossi et al. 2010; Rossi and Reichenbach 2016). For each pixel (circles) in the training dataset, the plot shows the average susceptibility value and their variability expressed by 2 standard deviations. Red line is a parabolic uncertainty model fitting the data, which is used to assign an uncertainty value to each pixel in the entire regional territory. The geographical distribution of the uncertainty values is shown in Fig. A.1f. 


\section{Appendix B}

Table B.1 Description of the intended use categories of buildings as listed in the OMI database (AdTTecnoborsa 2008; Osservatorio del Mercato Immobiliare 2017). In italic the original terms expressed in Italian language

\begin{tabular}{|c|c|c|}
\hline $\begin{array}{l}\text { Intended use } \\
\text { category } \\
\text { (destinazione) }\end{array}$ & $\begin{array}{l}\text { Typology } \\
\text { (tipologia) }\end{array}$ & Description \\
\hline \multirow[t]{6}{*}{$\begin{array}{l}\text { Residential } \\
\text { (residenziale) }\end{array}$} & $\begin{array}{l}\text { Villa } \\
\text { (ville e villini) }\end{array}$ & Private house with garden \\
\hline & $\begin{array}{l}\text { Refined house } \\
\text { (abitazione signorile) }\end{array}$ & Residential building with precious architectural features \\
\hline & $\begin{array}{l}\text { Residential unit } \\
\text { (abitazione civile) }\end{array}$ & Residential building with good general characteristics \\
\hline & $\begin{array}{l}\text { Economical residential } \\
\text { unit } \\
\text { (abitazione di tipo } \\
\text { economico) }\end{array}$ & Residential building with economical characteristics \\
\hline & $\begin{array}{l}\text { Boxe and garage } \\
\text { (box e autorimessa) }\end{array}$ & $\begin{array}{l}\text { Private isolated unit or part of a building dedicated to } \\
\text { parking }\end{array}$ \\
\hline & $\begin{array}{l}\text { Covered/uncovered } \\
\text { parking } \\
\text { (posto auto coperto e } \\
\text { scoperto) }\end{array}$ & Private parking lot \\
\hline \multirow[t]{3}{*}{$\begin{array}{l}\text { Commercial } \\
\text { (commerciale) }\end{array}$} & $\begin{array}{l}\text { Shop } \\
\text { (negozio) }\end{array}$ & $\begin{array}{l}\text { Real estate unit intended for wholesale or retail com- } \\
\text { merce }\end{array}$ \\
\hline & $\begin{array}{l}\text { Shopping center } \\
\text { (centro commerciale) }\end{array}$ & Building or complex of buildings with shops \\
\hline & $\begin{array}{l}\text { Warehouse } \\
\text { (magazzino) }\end{array}$ & Real estate unit for commercial use \\
\hline \multirow[t]{2}{*}{$\begin{array}{l}\text { Service sector } \\
\text { (terziario) }\end{array}$} & $\begin{array}{l}\text { Office } \\
\text { (ufficio) }\end{array}$ & Real estate unit for office use \\
\hline & $\begin{array}{l}\text { Structured office } \\
\text { (ufficio) }\end{array}$ & Building for office use \\
\hline \multirow[t]{3}{*}{$\begin{array}{l}\text { Productive } \\
(\text { produttivo })\end{array}$} & $\begin{array}{l}\text { Shed } \\
\text { (capannone) }\end{array}$ & $\begin{array}{l}\text { Shed characterized by the homogeneity of the construc- } \\
\text { tion typology and architectural features, compared to } \\
\text { the territorial area in which it is located }\end{array}$ \\
\hline & $\begin{array}{l}\text { Industrial shed } \\
\text { (capannone industri- } \\
\text { ale) }\end{array}$ & Shed used for industrial activity \\
\hline & $\begin{array}{l}\text { Laboratories } \\
\text { (laboratori) }\end{array}$ & $\begin{array}{l}\text { Real estate unit or building for tertiary destination, used } \\
\text { for of artisan work of a non-business character, with } \\
\text { possible retail sales }\end{array}$ \\
\hline
\end{tabular}




\section{References}

AdT-Tecnoborsa (2008) Glossario delle definizioni tecniche in uso nel settore economico-immobiliare - Edizione II. https://www.tecnoborsa.com/Media/Default/doc_glossario/Glossario_AdT_ Tecnoborsa_edizII-2008.pdf. Last access 11 August 2020

Alexander ED (2005) Vulnerability to landslides. In: Glade T, Anderson MG, Crozier MJ (eds) Landslide risk assessment. John Wiley, New York, pp 175-198

Antonini G, Ardizzone F, Cardinali M, Galli M, Guzzetti F, Reichenbach P (2002) Surface deposits and landslide inventory map of the area affected by the 1997 Umbria-Marche earthquakes. Boll Soc Geol Ital 121(1):843-853

Ardizzone F, Cardinali M, Guzzetti F, Reichenbach P (2008) Landslide hazard assessment, vulnerability estimation, and risk evaluation at the basin scale. In: Proceedings of the first landslide forum. Nations University, Tokyo, pp 71-74

Bathrellos GD, Gaki-Papanastassiou K, Skilodimou HD, Papanastassiou D, Chousianitis KG (2012) Potential suitability for urban planning and industry development using natural hazard maps and geological-geomorphological parameters. Environ Earth Sci 66(2):537-548

Benson C, Clay E (2004) Understanding the economic and financial impacts of natural disasters. The World Bank, Washington DC

Berdegué JA, Carriazo F, Jara B, Modrego F, Soloaga I (2015) Cities, territories, and inclusive growth: Unraveling urban-rural linkages in Chile, Colombia, and Mexico. World Dev 73:56-71

Bertolaso, Boschi (2007) I terremoti dell'Appennino umbro-marchigiano I secolo a.C.- 2000. Presidenza del Consiglio dei Ministri, Roma

Bornaetxea T, Rossi M, Marchesini I, Alvioli M (2018) Effective surveyed area and its role in statistical landslide susceptibility assessments. Nat Hazards Earth Syst Sci 18(9):2455-2469

Boschi E, Guidoboni E, Ferrari G, Valensise G, Gasperini P (1997) Catalogo dei forti terremoti in Italia dal 461 a.C. al 1990 vol 2. ING-SGA, Bologna

Brabb EE (1984) Innovative approach to landslide hazard and riskmapping. In: Proceedings of the 4th International Symposium on Landslides Toronto. vol 1, pp 307-324

Cardinali M, Reichenbach P, Guzzetti F, Ardizzone F, Antonini G, Galli M, Salvati P et al (2002) A geomorphological approach to the estimation of landslide hazards and risks in Umbria, Central Italy. Nat Hazards Earth Syst Sci 2:57-72

Cardinali M, Antonini G, Reichenbach P, Guzzetti F (2001) Photo-geological and landslide inventory map of the Upper Tiber River basin. CNR GNDCI publication number 2154. CNR GNDCI, (map at 1:100 000 scale), Roma

Chung CJF, Fabbri AG (1999) Probabilistic prediction models for landslide hazard mapping. Photogramm Eng Remote Sens 65(12):1389-1399

Chung CJF, Fabbri AG (2003) Validation of spatial prediction models for landslide hazard mapping. Nat Hazards 30(3):451-472

DeGraff JV (2012) Solving the dilemma of transforming landslide hazard maps into effective policy and regulations. Nat Hazards Earth Syst Sci 12(1):53-60

DiPasquale D, Wheaton WC (1996) Urban economics and real estate markets. Prentice Hall, Englewood Cliffs, NJ

Donnini M, Napolitano E, Salvati P, Ardizzone F, Bucci F, Fiorucci F, Guzzetti F et al (2017) Impact of event landslides on road networks: a statistical analysis of two Italian case studies. Landslides 14(4):1521-1535

Engelhardt GV (1994) House prices and the decision to save for down payments. J Urban Econ $36(2): 209-237$

Fawcett T (2006) An introduction to ROC analysis. Pattern Recognit Lett 27(8):861-874

Felicioni G, Martini E, Ribaldi C (1994) Studio dei centri abitati instabili in Umbria: atlante regionale: pubblicazione n. 979 del GNDCI-CNR. Rubbettino, Soveria Mannelli (Catanzaro)

Field CB, Barros V, Stocker TF, Dahe Q (Eds) (2012) Managing the risks of extreme events and disasters to advance climate change adaptation: special report of the intergovernmental panel on climate change. Cambridge University Press, Cambridge

Friedman M (1957) The permanent income hypothesis. In: A theory of the consumption function. Princeton University Press, pp 20-37, Princeton

Froude MJ, Petley DN (2018) Global fatal landslide occurrence from 2004 to 2016. Nat Hazards Earth Syst Sci 18:2161-2181. https://doi.org/10.5194/nhess-18-2161-2018 
Geneletti D, Bagli S, Napolitano P, Pistocchi A (2007) Spatial decision support for strategic environmental assessment of land use plans. A case study in southern Italy. Environ Impact Assess Rev 27(5):408-423

Glade T, Crozier MJ (2005) Landslide hazard and risk: concluding comment and perspectives. In: Landslide hazard and risk. Wiley, Chichester, pp 767-774

Guzzetti F (2006) Landslide hazard and risk assessment. PhD Thesis. Universitäts- und Landesbibliothek, Bonn

Guzzetti F, Cardinali M (1989) Carta Inventario dei Fenomeni Franosi della Regione dell'Umbria ed aree limitrofe. CNR-GNDCI, Publication no. 204 (2 sheets, scale 1:100,000 (in Italian))

Guzzetti F, Cardinali M, Reichenbach P (1996) The influence of structural setting and lithology on landslide type and pattern. Environ Eng Geosci 2(4):531-555

Guzzetti F, Carrara A, Cardinali M, Reichenbach P (1999) Landslide hazard evaluation: a review of current techniques and their application in a multi-scale study, Central Italy. Geomorphology 31(1-4):181-216

Guzzetti F, Galli M, Reichenbach P, Ardizzone F, Cardinali MJNH (2006b) Landslide hazard assessment in the Collazzone area, Umbria, Central Italy. Nat Hazards Earth Syst Sci 6(1):115-131

Guzzetti F, Reichenbach P, Ardizzone F, Cardinali M, Galli M (2006a) Estimating the quality of landslide susceptibility models. Geomorphology 81(1/2):166-184

Guzzetti F, Reichenbach P, Cardinali M, Ardizzone F, Galli M (2003) The impact of landslides in the Umbria region, central Italy. Nat Hazards Earth Syst Sci 3(5):469-486

Guzzetti F, Reichenbach P, Cardinali M, Galli M, Ardizzone F (2005) Probabilistic landslide hazard assessment at the basin scale. Geomorphology 72(1-4):272-299

Haurin D, Rosenthal SS (2006) House price appreciation, savings, and consumer expenditures. HUD $5: 1-45$

Herath S, Wang Y (2009) Case studies and national experiences. In: Landslides-disaster risk reduction. Springer, Berlin, Heidelberg, pp 475-497

Hungr O, Clague JJ, Morgenstern NR, VanDine DF, Stadel D (2016) A review of landslide risk acceptability practices in various countries. In Proceedings of the 12th International Symposium on Landslides (pp. 12-19), Napoli

Iovino L, D'Emidio M, Modica M (2020) Creating an holistic emergency alert management platform. J Urban Technol 27(2):3-20

Keiler M (2004) Development of the damage potential resulting from avalanche risk in the period 1950-2000, case study Galtür. Nat Hazards Earth Syst Sci 4(2):249-256

Klimeš J, Blahůt J (2012) Landslide risk analysis and its application in regional planning: an example from the highlands of the Outer Western Carpathians, Czech Republic. Nat Hazards 64(2):1779-1803

Linnerooth-Bayer J, Patt A (2016) Introduction to the special issue on rethinking participatory processes: the case of landslide risk in Nocera Inferiore. Nat Hazards 81:1-6

Mancini F (1966) Carta Dei Suoli d'Italia 1: 1000 000: Soil Map of Italy. Società geografica, Firenze

Marin G, Modica M (2017) Socio-economic exposure to natural disasters. Environ Impact Assess Rev 64:57-66

Marx B, Stoker T, Suri T (2013) The economics of slums in the developing world. J Econ Perspect 27(4):187-210

Mateos RM, Garcia I, Del Ventisette C, Ciampalini A, Arizzone F, Rossi M, Simoniello T, Malamud BD (2014) D6.1. Landslide susceptibility models and maps. LAMPRE Project. www.lampreproject.eu/index.php?option=com_phocadownload\&view=category\&download=33:d6-1-reporton-landslide-susceptibility-models-and-maps-pdf-1-7-mb\&id=7:wp6-preparedeness-preventionrecovery-reconstruction. Last access 11 August 2020

Merz B, Hall J, Disse M, Schumann A (2010) Fluvial flood risk management in a changing world. Nat Hazards Earth Syst Sci 10(3):509-527

Meyer V, Becker N, Markantonis V, Schwarze R, van den Bergh JCJM, Bouwer LM, Bubeck P, Ciavola P, Genovese E, Green C, Hallegatte S, Kreibich H, Lequeux Q, Logar I, Papyrakis E, Pfurtscheller C, Poussin J, Przyluski V, Thieken AH, Viavattene C (2013) Review article: assessing the costs of natural hazards - state of the art and knowledge gaps. Nat Hazards Earth Sys 13:1351-1373

Michael-Leiba M, Baynes F, Scott G, Granger K (2003) Regional landslide risk to the Cairns community. Nat Hazards 30(2):233-249

Miller DL, Page ME, Huff Stevens A, Filipski M (2009) Why are recessions good for your health? Am Econ Rev Pap Proc 99:122-127

Modica M, Zoboli R (2016) Vulnerability, resilience, hazard, risk, damage, and loss: a socio-ecological framework for natural disaster analysis. Web Ecol 16(1):59-62 
Modica M, Faggian A, Aloisio R (2019) The post-earthquake reconstruction in L'Aquila: some reflections. Sci Reg 18(3):515-522

Mysiak J, Testella F, Bonaiuto M, Carrus G, De Dominicis S, Ganucci Cancellieri U, Firus K, Grifoni P (2013) Flood risk management in Italy: challenges and opportunities for the implementation of the EU Floods Directive (2007/60/EC). Nat Hazards Earth Syst Sci 13:2883-2890. https://doi.org/10. 5194/nhess-13-2883-2013

Nüst D, Granell C, Hofer B, Konkol M, Ostermann FO, Sileryte R, Cerutti V (2018) Reproducible research and GIScience: an evaluation using AGILE conference papers. PeerJ 6:e5072

Osservatorio del Mercato Immobiliare (2017) Manuale della Banca Dati Quotazioni dell'Osservatorio del Mercato Immobiliare. Istruzioni tecniche per la formazione della Banca Dati Quotazioni OMI. https:// www.agenziaentrate.gov.it/portale/documents/20143/265514/omi+sintesi+manuale+bdq_Sintesi_ Manuale_BDQ_OMI.pdf/7af98c25-a219-3cc6-d897-aa6d98e072be. Last access 11 August 2020

Osservatorio del Mercato Immobiliare (2018) Manuale della banca dati dell'OMI, Versione 2.0. https:// www.agenziaentrate.gov.it/portale/documents/20143/265514/I1+manuale+della+banca+dati+OMI_ Manuale+2016_vers_2.0+modificata+in+data+02-01-2018.pdf/c2073cce-b58f-cc2d-4827-d52a8b5e ac95. Last access 11 August 2020

Ozanne L, Thibodeau T (1983) Explaining metropolitan housing price differences. J Urban Econ 13(1):51-66

Paleari S (2018) Natural disasters in Italy: do we invest enough in risk prevention and mitigation? Int J Environ Stud 75(4):673-687. https://doi.org/10.1080/00207233.2017.1418995

Pelling M (2003) The vulnerability of cities: natural disasters and social resilience. Earthscan, London

Prenger-Berninghoff K, Greiving S (2015) The use of risk information in spatial planning in Europe: examples from case study sites in Italy and Romania with a focus on flood and landslide hazards. In: Engineering geology for society and territory, vol 5. Springer, Cham, pp 737-741

Promper C, Glade T (2016) Multilayer-exposure maps as a basis for a regional vulnerability assessment for landslides: applied in Waidhofen/Ybbs, Austria. Nat Hazards 82(1):111-127

Reichenbach P, Rossi M, Malamud BD, Mihir M, Guzzetti F (2018) A review of statistically-based landslide susceptibility models. Earth Sci Rev 180:60-91

Rossi M, Reichenbach P (2016) LAND-SE: a software for statistically based landslide susceptibility zonation, version 1.0. Geosci Model Dev 9(10):3533-3543

Rossi M, Guzzetti F, Reichenbach P, Mondini AC, Peruccacci S (2010) Optimal landslide susceptibility zonation based on multiple forecasts. Geomorphology 114(3):129-142

Schlögel R, Marchesini I, Alvioli M, Reichenbach P, Rossi M, Malet JP (2018) Optimizing landslide susceptibility zonation: effects of DEM spatial resolution and slope unit delineation on logistic regression models. Geomorphology 301:10-20

Schuster RL, Highland L (2001) Socioeconomic and environmental impacts of landslides in the western hemisphere. US Department of the Interior, US Geological Survey, Denver (CO)

Servizio Geologico Nazionale (1980) Carta Geologica dell’Umbria. Servizio Geologico Nazionale, (Map at 1:250 000 scale, (in Italian)), Roma

Sheiner L (1995) Housing prices and the savings of renters. J Urban Econ 38(1):94-125

Takayama T, Judge GG (1970) Alternative spatial equilibrium models. J Reg Sci 10(1):1-12

UNISDR, UNDP, IUCN (2009) Making disaster risk reduction gender sensitive: policy and practical guidelines. United Nations, Geneva

Wieand KF (1987) An extension of the monocentric urban spatial equilibrium model to a multicenter setting: the case of the two-center city. J Urban Econ 21(3):259-271

Publisher's Note Springer Nature remains neutral with regard to jurisdictional claims in published maps and institutional affiliations. 